Acta Universitatis Wratislaviensis No 3998

Anglica Wratislaviensia LVIII, Wrocław 2020

https://doi.org/10.19195/0301-7966.58.6

\author{
Marcin Tereszewski \\ ORCID: 0000-0001-8012-9039 \\ University of Wrocław \\ marcin.tereszewski@uwr.edu.pl
}

\title{
Illusion and Compensation: Heterotopic Aspects of Gated Communities in J. G. Ballard's Fiction
}

\begin{abstract}
Gated communities have come to mean more than simple building structures and their predominantly negative cultural representation has become somewhat of a commonplace trope in literature and urban studies. This paper sets out to explore the assumptions underpinning the overwhelmingly dystopian representations of gated communities in literature and culture. This inquiry will be carried out with reference to J. G. Ballard's depictions of gated communities in his later work, particularly in Cocaine Nights (1996) and Super Cannes (2000) and will be carried out within the context of Michel Foucault's concept of heterotopia. It will be the contention of this paper that gated communities can also be construed as providing a heterotopic zone of subversive topography, which serves not to reinforce, but in fact challenge the dominant urban setting.
\end{abstract}

Keywords: heterotopia, gated communities, J. G. Ballard, spatiality

There is a particular stigma attached to gated communities in both urban studies and literature. This usually one-sided and unequivocally dystopian depiction usually presents gated communities as sites of urban neoliberalism and a transnational "gating machine", with such imagery as "bunker mentality" and "fortress cities" being used to describe environments which purportedly deprive the individual of agency and personal freedom. There is a distinct Marxist perspective that informs these analyses, one which tends to stress the capitalist and exploitative effects of spatial appropriation, gentrification, post-civil corporate capitalism, condemning this trend as anti-social and detrimental to the cohesiveness of society. Constrained to a Marxist context and thus limited in scope, such analyses usually ignore the ambiguity that is at the heart of the gated community. In order to explore the ambiguities generated by gated communities, this paper will examine the self-enclosed enclaves found in James Graham Ballard's later fictions, especially Super-Cannes (2000) and Cocaine Nights (1996), through a consideration of Foucault's notion of heterotopia. 
The appearance of suburbs and gated communities was more than a development in urban studies; it also sparked a debate as a cultural phenomenon. American science fiction of the 1950s and 1960s, as well as an entire suburban gothic subgenre, was quick to pick up on the artistic possibilities generated by the new and rapidly shifting terrain of the suburban sprawl, seeing in it a symbol of $1950 \mathrm{~s}$ middle-American hegemony. It is precisely this hegemony that much of the literature devoted to this subject sought to challenge and expose. Ray Bradbury's Martian Chronicles, Philip K. Dicks Time Out of Joint, Shirley Jackson's The Haunting of Hill House (1959), and Ira Levin's The Stepford Wives (1972) are just some of the many twentieth-century novels which incorporate the suburban environment as an integral element in the dystopian themes they develop. All of them take issue with some form of imposed hierarchy, whether it takes the form of patriarchy or despotic dehumanized rituals. The genre then spilled into film with Peter Weir's The Truman Show and David Lynch's Twin Peaks, which, albeit in different ways, presented the suburbs as a kind of artificial prison and the inhabitants as its unwitting prisoners. Suffice it to say, gated communities and the suburbs have offered literature and film an evocative spatial construct to represent the failings of modern capitalist society, but they have rarely been examined as places of resistance, only conformism.

Spatial considerations occupy a central place in Ballard's novels and short stories. At various points in his literary career, Ballard has made use of post-apocalyptic environments, hyper-urbanized settings, images of war-torn Shanghai from his childhood, and self-enclosed enclaves resembling gated communities, all of which have provided Ballard with the means to assess the impact various spatial configurations have on the development of psychopathological behaviour. It is perhaps at this point, at the intersection of psychological aberrations and spatial determinants, that Foucault's notion of heterotopia can bring about a new perspective on how gated communities can be read in dystopian fiction.

In a lecture for architects in 1967 (published in 1984) entitled "OfOther Spaces" (Des espaces auters), Michel Foucault developed the concept of heterotopia, a term which had appeared briefly in The Order of Things, though in a more linguistic context, describing its "disturbing" ability to "shatter or tangle common names" and to "destroy 'syntax' with which we construct sentences" (viii). This term is never clearly fleshed out in Foucault's writing, thus generating a multitude of contradictory interpretations, applications and misapplications. Perhaps this vagueness lent the concept some mystique, attracting many academics to incorporate it into their research, most notably David Harvey and Edward Soja. The latter's description of Foucault's heterotopia as "frustratingly incomplete, inconsistent, incoherent" (162) partly explains why the term has tended to mean slightly different things in the hands of various writers, thus exasperating the already confused state of the term. This ambivalence and uncertainty inherent in heterotopias, Soja claims, results from the multiplicity of social meanings attached to them, famously 
using the example of downtown LA to illustrate the concept, while Henry Lefebvre understands heterotopias as spaces that are marginalized within the dominant social spatialization.

The concept of heterotopia has been widely used to conceptualize various institutions and places that interrupt the apparent continuity and normality of ordinary everyday space. Because they inject alterity and otherness into otherwise hegemonic structures of everyday life, Foucault called these places "hetero-topias"- literally meaning "other places". These places can be regarded utopian in that they exist beyond all other places, but unlike utopias, they can have a precise location. These are real places, oftentimes the by-products of modern architectural urbanization, such as shopping malls, hotels, amusement parks.

Foucault begins "Of Other Spaces" with the oft-quoted assertion that "the present epoch will perhaps be above all the epoch of space" (14) before developing a brief outline of the history of Western conceptions of space, since it is now space that has superseded time as the defining feature of modernity. He begins his history with a description of the hierarchical space of the Middle Ages and then moves to the space of Cartesian extension in early modernity, until what he calls the space of emplacement of the present day, conceptualized as a network or grid. What this historical survey of heterotopias illustrates is that the function of heterotopias changes, adjusting to spatio-social conditions that are currently in effect.

An important element of heterotopias is the idea that heterotopias cannot exist in and of themselves, but only in relation to already existing spaces. Because they are relational, heterotopias have a function in relation to these already-established spaces.

Either their role is to create a space of illusion that exposes all real space, all the emplacements in the interior of which human life is enclosed and partitioned, as even more illusory ... or else, on the contrary, creating another space, another real space, as perfect, as meticulous, as well-arranged as ours is disorderly, ill construed and sketchy. (21)

Foucault thus distinguishes two functions of heterotopias: illusory and compensatory. Heterotopias of illusion create spaces of illusion that expose the rest of space as enclosed and partitioned, such as brothels, cinemas, libraries, oriental gardens. These are potentially subversive spaces offering resistance to the regime of order. Heterotopias of compensation, on the other hand, create real spaces that are nonetheless "other" to established spaces. Examples of such heterotopias include monasteries, schools and prisons; these are enclosures, separated from the outside world, where all features of life are carefully regulated. Heterotopias have thus fallen into two categories. One category sees them as spaces of subversion, points of resistance to hegemonic structures, spaces that, as Ken Hetherington describes them, "capture something of the significance of sites of marginality that act as postmodern spaces for resistance and transgression" (42), whereas the other category presents heterotopias as carceral institutions, such as prisons and hospitals, which function according to a strict set of rules and regulations. Hetherington 
warns us not to fall into any one-sided view of heterotopia, which is why he presents heterotopias as "spaces of alternative social ordering" (40), indeed a rather broad description that combines these two trajectories. Heterotopias can be instruments of normalization and order, extending hegemonic power relations, as well as spaces of otherness characterized by radical openness. It is precisely this tension between what Foucault termed the heterotopias of illusion and the heterotopias of compensation that best reflect the ambiguous spatial dynamic in Ballard's fiction. What is more, Peter Jonson notes that heterotopias also problematize utopian spaces, to which we may include gated communities, by "imaginatively interrogat[ing] and undermin[ing] certain formulations of utopia" (75).

Before proceeding to an analysis of Ballard's works, a few words are necessary to position gated communities as heterotopias. Setha Low's study of gated communities in Behind the Gates: Life, Security, and the Pursuit of Happiness in Fortress America and especially in her contribution to Heterotopia and the City: Public Space in a Post-civil Society provides an important reading of the heterotopic aspects of gated communities. Low claims that gated communities represent a variation of the heterotopic effect of blurring the public/private dichotomy mentioned by Foucault in "Of Other Spaces". Heterotopias tend to blur the public/private distinction and this is an oft-cited criticism of gated communities, which are often accused of privatizing public space and cordoning it off for private, exclusive use. "This intermingling of public space and private law may be symptomatic of the 'perverse effects of blurring boundaries' characteristic of heterotopias, and is often considered a kind of 'club realm' from an economic perspective" (Low, "The Gated Community" 160). Gated communities further redefine traditional distinctions between public and private space by erecting conceptual and physical borders to separate themselves from the external world. As Low states, gated communities are defined by "visible barriers that have social and psychological as well as physical effects" (Low, Behind the Gates 12). These barriers work to foster a sense of security by exaggerating the distinction between insiders and outsiders, while at the same time exacerbating the anxiety towards the other which necessitated the creation of gated communities in the first place.

This leads me to a related, and final, aspect of gated communities, which went undeveloped by Low, but one that I believe has an important connection with heterotopias, namely, the pervasive fictionality, or constructedness that underpins the experience of the heterotopia and gated communities. "Like other heterotopias such as military bases or hospitals, the sense of sanctuary is produced both by physical boundaries and by a special discourse that reinforces the importance of these boundaries as a means of protection" (Low, "The Gated Community" 155). This notion of "special discourse' is very important in establishing heterotopias; however, the exact meaning of this discourse remains enigmatic, suggesting only the need for a supporting ideology to bring to life the desired illusion. One of the purposes of gated communities and suburbs in general has been to recreate an im- 
age of utopian community, one that is based on the desire for safety (as we have already indicated earlier) but also on mythic and nostalgic imagery. There is therefore a very strong element of fictionality that is needed to prop up the ideological structure of gated communities, which apart from providing a false sense of security (statistical data does prove that gated communities are in no way safer), also fulfil an arguably more important desire of its denizens; namely, to live out a mythologized and utopian version of middle-class life. This "special discourse" is therefore a utopian discourse generating a fictionalized environment in which the imagined fantasy is lived out.

As mentioned earlier, there is a strong utopian strand running through the idea of gated communities; however, unlike the intentional communities of the nineteenth and twentieth century that came before them, modern-day gated communities are predicated on capitalist values and materialist aims. Edward J. Blakely and Mary Gail Snyder explain that "gated communities have their antecedents in modern utopias, but they have been transformed into a totally new product, organized and marketed as a solution to contemporary problems rather than as a search for a better communal system" (Blakely and Snyder 15). The utopian dream of a better world is here replaced with more pragmatic solutions centred more on capitalist, rather than purely social, values, in which case gated communities can be regarded as a commodified version of nineteenth century intentional communities. Instead of secular or religious ideology paving the way towards a new utopia as a critique of the world outside its walls, these new utopias, i.e. gated communities, have been co-opted by capitalism in such a way as to divest them of any critical force they might have had.

It is here that we arrive at the aporetic logic we earlier formulated with regards to heterotopias: how can gated communities, given their fictionality and complicity with the hegemonic corporate logic of global capitalism, at the same time operate as places of resistance in the heterotopic sense? Further, how can gated communities, which mimic the utopic pretensions of modernist architecture based on order, also invite disorder? J. G. Ballard's fiction goes some way towards answering this question.

Ballard's international reputation rests mainly on the fame of Empire of the Sun and the infamy of Crash, as well as his role as a provocateur within the science fiction genre, pioneering the subgenre of New Wave science fiction. This is why his later literary output might seem out of character, as it is more in the vein of crime and mystery conventions than science fiction, with the setting of these stories usually straying towards the suburbs and gated communities away from post-apocalyptic environments (The Drowned World, The Drought) or urban settings (High-Rise). Ballard's later works dealing with the discussed subject matter include Cocaine Nights (1996) and Super-Cannes (2001), Millennial People (2003) and Running Wild (1988). Each book addresses a particular developmental trajectory of contemporary self-enclosed spaces, drawing attention to the possible in- 
herent psychopathologies that arise from these particular social enclosures. There is general agreement among scholars of Ballard's fiction that the spaces depicted in these works represent some variant of gated communities in that in all cases we are dealing with enclosed spaces which exist apart from the outside world, spaces in which society is ordered along singular, often mysterious, principles. Gasiorek emphasizes the defensive function of these communities, indicating that in Ballard's later work "there is a shift from a concern with temporality to a preoccupation with spatiality, particularly with a defence of physical space, which is seen to be under threat from external aggression, and a retreat from outside space to psychological interiority" (186). As these spaces operate on the basis of their own social order where normative rules seem to be suspended, they comply with the function of heterotopias.

To best flesh out the distinct spatial attributes of heterotopias in Ballard's work, we will turn our attention to how gated communities function in the above mentioned works. Cocaine Nights depicts Estrella de Mar, a Spanish leisure community for the wealthy, where we as readers are invited to follow the protagonist in his investigation of a murder. Super-Cannes presents Eden-Olympia, an elitist corporate enclave in southern France modelled after the real business park, Sophia Antipolis, which, as noted by Paddy, "follows very much the same pattern as Cocaine Nights ... What Super-Cannes adds to the equation a stronger economic element ... Where Cocaine Nights examines the role violence plays in the building of a community, Super-Cannes looks to its role violence plays in sustaining multinational, neoliberal capitalism" (273), which, as mentioned earlier, represents the economic basis for the existence of gated communities. Though both of these gated communities are built on the utopian idea of order and security, tucked neatly away from the messiness and chaos of the outside world, they are each nonetheless tainted by an inexplicable violent event, one that would have otherwise threatened to dismantle the ideals on which these gated communities are built if not for the fact that this violence seems to be embedded in the makeup of these environments, much like a relief valve releasing pent-up pressure.

As has already been mentioned, these books represent a new chapter in Ballard's career in which he turned to the genre of the crime novel (or perhaps more accurately) murder mystery, though it must be emphasized that his particular version of the crime novel genre departs from the tradition, in that the central crime is already solved at the outset of the narrative. "Ballard's murder mysteries do not ask to be solved, for there is no definitive truth or reality to be recovered. Rather, these texts demand a process of readerly investigation which opens the transparent surfaces of contemporary history and culture up to the revealing powers of paradox and ambiguity" (Baxter 172). Therefore, the focus is shifted from resolution of the crime to its after-effects or to the psychological motive of the crime, which is psychogeographically tied to the kind of environment that may have contributed to these sudden eruptions of violence. 
Super-Cannes begins with the protagonist, Paul Sinclair, on his way with this wife, Jane, to Eden-Olympia, where she is to replace another physician, David Greenwood, who months before went on a murderous rampage, gunning down seven senior citizens before taking his own life. Paul Sinclair, unemployed and therefore with some free time on his hands, takes an interest in this mystery and proceeds to investigate the circumstances of the crime. During the course of his investigation, he uncovers the dark underbelly of the utopian park hidden beneath the veneer of an idyllic setting and conveniences, and this triggers Greenwood's gradual descent into violence.

For Samuel Francis "Super-Cannes enacts a speculative interrogation of the psychology of postmodern corporatism" (162). Indeed the spectre of commodification and corporate capitalism looms large above all these gated communities, all of which have been established in line with capitalist pursuits (leisure, work, shopping, residence). It is impossible not to have the impression that the main reason for their existence is to serve at the behest of capitalist interests. Resembling a "high-tech science park", with its "antiseptic quality", Eden-Olympia embodies the corporate idea of an ideal community. For example, the efficiency demanded from the inhabitants of Eden-Olympia can be seen as a more nefarious extension of Taylorism, especially since the people living in this environment are unaware that they are being exploited. The pervasiveness and the extent of the social engineering project help to conceal it from the people living within its borders.

Ballard draws attention to the psychological effects of such an environment. It appears that living in such a perfectly streamlined environment surrounded by architecture that only reinforces the necessity to surrender oneself to productive pursuits dulls the senses and leads to a state of intellectual and moral stupor. In Super-Cannes, Penrose, the psychiatrist in Ballard's fictional French business park, believes that there is a science to this process: "Part of the mind atrophies. A moral calculus that took thousands of years to develop starts to wither from neglect. Once you dispense with morality the important decisions become a matter of aesthetics. You've entered an adolescent world where you define yourself by the kind of trainers you wear" (Ballard, Super-Cannes 255-56). This is a similar criticism that has been levelled at suburbanites. A gradual corrosion of the more nuanced aspects of human existence, notably morality and self-awareness, ensues; the vita contemplativa is wholly superseded by the vita active, though it is activity entirely conforming to the expectations and precepts of the anodyne culture that seems to control every facet of life. As Penrose goes on to explain, the "great defect is that there is no need for personal morality. Thousands of people live and work here without making a single decision about right and wrong. The moral order is engineered into their lives along with the speed limits and the security systems" (Ballard, Super-Cannes 255). This would represent the continuation of social engineering projects, which also sought to imbue architectural planning with a moral purpose. 
What becomes clear in this rather dystopian representation of a gated community is that the antiseptic environment is ultimately responsible for the violence the residents are inflicting upon themselves. Gasiorek claims that this violence "functions as a fantasised means of re-enchanting the world" (202). Though this is something that could be said about High-Rise, the kind of violence witnessed in Super-Cannes is of a completely different variety, as it is embedded within the community itself. It could therefore be argued that these community enclaves oppose the normalized society by sanctioning certain kinds of criminal activity, which work to sustain the fictional equilibrium. Through a complex repositioning of crime as communal, Ballard asks a series of important questions about the nature of community and violence in contemporary society.

Cocaine Nights takes place on the Costa del Sol in the imagined Estrella de Mar gated community inhabited by British expatriates. The utopian character of this gated community is enforced by it being characterized as being outside any particular place; it "isn't anywhere" (Cocaine Nights). Despite its utopian veneer as a leisure community for the well-to-do, Estrella de Mar is a site of a murder, supposedly perpetuated by the protagonist's brother, Charles Prentice, who arrives to investigate the circumstances of this crime. Charles's arrival in Estrella de Mar is prefaced by a strikingly heterotopic description: "Crossing frontiers is my profession. Those strips of no-man's land between the checkpoints always seem such zones of promise, rich with the possibilities of new lives, new scents and affections. At the same time they set off a reflex of unease that I have never been able to repress" (Ballard, Cocaine Nights 9). As is often the case in Ballard's fiction, the importance of the plot is matched by the role the environment plays as a kind of suspect of this crime, in this case the "zones of promise" which are governed by unclear rules.

One of the defining features of this gated community is the ubiquity of leisure. Ballard quite rightly places this fictitious town on the Costa del Sol, which had by the 1970s become a favourite area for Britons as a holiday and retirement getaway. For the inhabitants of Estrella de Mar, leisure has become a kind of profession performed with upmost seriousness. There is no paucity of film clubs, choral societies, and cordon bleu classes, which keep the inhabitants in a permanent state of distraction. However, this frivolous hedonism is tinged with a darker underside, which is also reflected in the real Costa del Sol, which is known not only as a holiday resort, but also through its more dubious reputation as a haven for British criminals. This works to add another more insidious dimension to the carefree unstructured leisure of Estrella de Mar.

Both novels attract a Freudian analysis and Samuel Francis's study of Ballard's fiction relies extensively on Freudian psychoanalysis, stressing that the violence prevalent in Ballard's gated communities is "an extrapolation of arguments advanced in Civilization and Its Discontents" (159). What this means is that this violence is representative of the subversive resistance our psychology mounts against civilizational repression, thereby standing in stark contrast to the remarkably dull 
and ordered existence these characters seem to be leading. "In their embrace of the libidinal gratifications of violence and sexuality, the denizens of Estrella de Mar reassert their individual liberties against a postmodern leisure society oriented around the subdual and constriction of human instinctual energies" (Francis 158-59). This certainly would explain the sudden bursts of violence in these wellregulated enclaves, violence which seems to have been communally sanctioned. The crime which brings Charles to the resort was committed by his brother, Frank, but, as he learns later, it was committed on the behest of the community. "A great crime was needed, something terrible and spectacular that would bind everyone together, seal them into a sense of guilt that would keep Estrella de Mar going for ever" (Ballard, Cocaine Nights 317).

However, though Francis's approach is well-founded, it seems to gloss over an important point of Ballard's fiction, which is that it is the environment and spatial ordering that is the source of this violent resistance. If, however, we were to approach these depictions of gated communities as heterotopic in their subversive potential, I believe another interpretive avenue emerges, one which would allow these heterotopias to provide a looking glass through which we may see in greater resolution the social contingencies at work in the dominant social structure.

The question then becomes whether Ballard's gated communities fall into the category of heterotopias of illusion or heterotopias of compensation discussed earlier. I would argue that they fulfil both functions. On the one hand, they stand in contrast to the disorganisation and discord that characterizes the world beyond their gates, thus making them, on first glance, heterotopias of compensation. They both present meticulously arranged enclaves reminiscent of utopian settings, where the whims of their respective residents are fulfilled as a matter of course. On the other hand, given their fictionality, i.e. their reliance on myth and nostalgia, and their false promise of security, they can be regarded as a space of illusion, exposing the subliminal narrative running through the social structures beyond the gates. That is, the spatial organization that goes into establishing a gated community is a reflection of the type of organization outside its walls and thus can serve as a more distilled, and thus more visible, manifestation of the often concealed ideological relations of power outside the walls of well-defined architectural spaces. This is certainly the case in such works as High-Rise, where the devolution to tribal instincts only reinforces similar social relations that exist in the corporate world; it is also the case in Cocaine Nights, where the social order within the enclaves serves to reflect the same tendencies of a capitalist, hedonistic society or of Super-Cannes, where corporate materialism is becomes the ideological blueprint for the creation of what on the surface is a utopian enclave.

Simon Sellers refers to such Ballardian enclaves as micronations on account of their self-sufficiency and self-governance; however, what seems to be particularly telling about this characterization is the implicit evocation of nations, i.e. macronations, which would share similar power structures of repressions, though 
in a much less visible way. Functioning as both mythic representations and real contestations of space, heterotopias are situated on the border between real and imaginary spaces, thus resonating with Ballard's imaginative transformation of physical spaces in his fiction. Ballard understands that space is never neutral and is inscribed with certain discourses, prohibitions and potentials; his texts thus open an important spatial paradigm that actively interrogates certain physical spaces to reveal those discourses producing alternative spatial orders, i.e. heterotopias. By embedding violence into the very fabric of purported utopias, Ballard draws attention to how gated communities, as enclosed spaces, encode questions of traumatic violence and communal sacrifice as both destructive and hopefully redemptive.

\section{References}

Ballard, J. G. 1996. Cocaine Nights. London-New York: Harper Perennial.

—. 2001. Super-Cannes. London: Flamingo.

Baxter, J. 2009. J. G. Ballard's Surrealist Imagination: Spectacular Authorship. Farnham: Ashgate Publishing Ltd.

Blakely, E. J. and M. G. Snyder. 1997. Fortress America: Gated Communities in the United States. Washington D.C.: Brookings Institution P.

Foucault, M. 1994. The Order of Things: An Archaeology of the Human Sciences. New York: Vintage Books.

—. 2008 [1986]. "Of Other Spaces.” In: Dehaene, M. and L. De Cauter (eds.). Heterotopia and the City: Public Space in a Postcivil Society. London: Routledge, 13-29.

Francis, S. 2011. The Psychological Fictions of J. G. Ballard. London: Continuum International Publishing.

Gasiorek, A. 2004. J. G. Ballard. Contemporary British Novelists. Manchester: Manchester UP.

Hetherington, K. 1997. The Badlands of Modernity: Heterotopia and Social Ordering. New YorkLondon: Routledge.

Johnson, P. 2006. “Unravelling Foucault's 'Different Spaces.”' History of the Human Sciences 19.4. $75-90$.

Low, S. 2003. Behind the Gates: Life, Security, and the Pursuit of Happiness in Fortress America. New York-London: Routledge.

—. 2008. "The Gated Community as Heterotopia." In: Dehaene, M. and L. De Cauter (eds.). Heterotopia and the City: Public Space in a Postcivil Society. London: Routledge, 153-63.

Paddy, D. I. 2015. The Empire of J. G. Ballard: An Imagined Geography. Canterbury: Gylphy.

Sellars, S. 2012. “'Zones of Transition': Micronationalism in the Work of J. G. Ballard.” In: Baxter J. and R. Wymer (eds.). J. G. Ballard: Visions and Revisions. New York and Basingstoke: Palgrave Macmillan, 230-48.

Soja, E. W. 1996. Thirdspace. Oxford: Blackwell. 